\title{
The US-Malaysia Maritime Security Cooperation and Implication Towards Malaysia's National Security
}

\author{
Mahamad Amer Musa1, Noraini Zulkifli2*(D) \\ 1Department of International Relations, Security and Law, Faculty of Management and Defence Studies, \\ National Defence University of Malaysia (UPNM), 57000, Kuala Lumpur, Malaysia. \\ Email: ameer252@yahoo.com \\ 2Department of International Relations, Security and Law, Faculty of Management and Defence Studies, \\ National Defence University of Malaysia (UPNM), 57000, Kuala Lumpur, Malaysia. \\ Email: noraini@upnm.edu.my
}

\section{CORRESPONDING \\ AUTHOR (*): \\ Noraini Zulkifli \\ (noraini@upnm.edu.my) \\ KEYWORDS: \\ Cooperation \\ Malaysia \\ Maritime Security \\ National Security \\ The US}

\section{CITATION:}

Mahamad Amer Musa \& Noraini Zulkifli. (2022). The US-Malaysia Maritime Security Cooperation and Implication Towards Malaysia's National Security. Malaysian Journal of Social Sciences and Humanities (MJSSH), 7(2), e001306.

https://doi.org/10.47405/mjssh.v7i2.1306

\begin{abstract}
Maritime security cooperation is a strategic approach engaged by the Malaysian government that involves a bilateral agreement with the United States (US), including the various agencies and organizations. The involvement with maritime security is due to the emergence of serious Non-Traditional Security (NTS) threats over the Malaysian waterways (Straits of Malacca, the South China Sea and the Sulu Sea in Eastern Sabah). The bilateral security cooperation aims to overcome the Malaysian government's gaps and limitations to govern its waterways. A qualitative method was used in this research to explain the implication of the US-Malaysia maritime security cooperation towards Malaysia's national security, specifically in the maritime domain, from 2010 until 2021. This research has three objectives, namely; 1) to investigate maritime security issues and challenges; 2) to identify the importance of the US Malaysia maritime security cooperation; 3) to analyze the implications of security cooperation towards Malaysia's national security. The national security concept was used in this research to support the maritime security collaboration between the US and Malaysia. This study found that Malaysia faces challenges and constraints from obsolescence, lack of maritime assets, and weaknesses in enforcing maritime laws, mainly dealing with increasing traditional and non-traditional security threats. Second, Malaysia can reduce the gap in the governance of maritime routes through bilateral security cooperation with the US. Third, Malaysia can maintain the peace and security of its maritime routes and improve and strengthen bilateral cooperation with the US through various stages, especially economic recovery in the post-pandemic era of COVID-19.
\end{abstract}

Contribution/Originality: This study contributes in the existing literature in the field of Maritime security in Malaysia. The study documents the cooperation between The US and Malaysia to enhance the security in Malaysia's waterway. 


\section{Introduction}

Malaysia is "strategically located on the Strait of Malacca, part of the South China Sea waterways (Central Intelligent Agency, 2021) and in the Asia Pacific Rim's centre, surrounded by several ASEAN countries, well-positioned and safe from severe natural catastrophes such as earthquakes, tsunamis, and typhoons (Labuan Business One Platform, 2021). Malaysia has a strategic waterway connecting the Pacific Ocean, and the Indian Ocean regions play an interrelated role in connecting, developing, and strengthening world relationships. The Malacca Strait and the Singapore Strait are the primary Sea Lines of Communication (SLOC) that connect the Indian Ocean to the Pacific Ocean via both waterways and the South China Sea, considered the busiest in the world (Maniati, 1998).

As observed in Figure 1, Malaysia is made up of Peninsular Malaysia (West Malaysia), which is part of mainland Southeast Asia, and the states of Sabah and Sarawak (East Malaysia), which are located on the northern borders of the island Borneo and are separated by the South China Sea (WorldAtlas, 2021). Furthermore, it is located at 0230 $\mathrm{N}, 11230 \mathrm{E}$, just north of the equator in central South-East Asia. East Malaysia is bordered to the south by Indonesia (Kalimantan), to the west and north by the South China Sea, to the northeast by the Sulu-Celebes Sea, and the northwest by Brunei in between Sabah and Sarawak (Commonwealth Governance, 2021). West Malaysia has marine boundaries with Thailand, Vietnam, Indonesia, and Singapore, whereas East Malaysia has maritime borders with Indonesia, Vietnam, and the Philippines.

Figure 1: Map of Malaysia

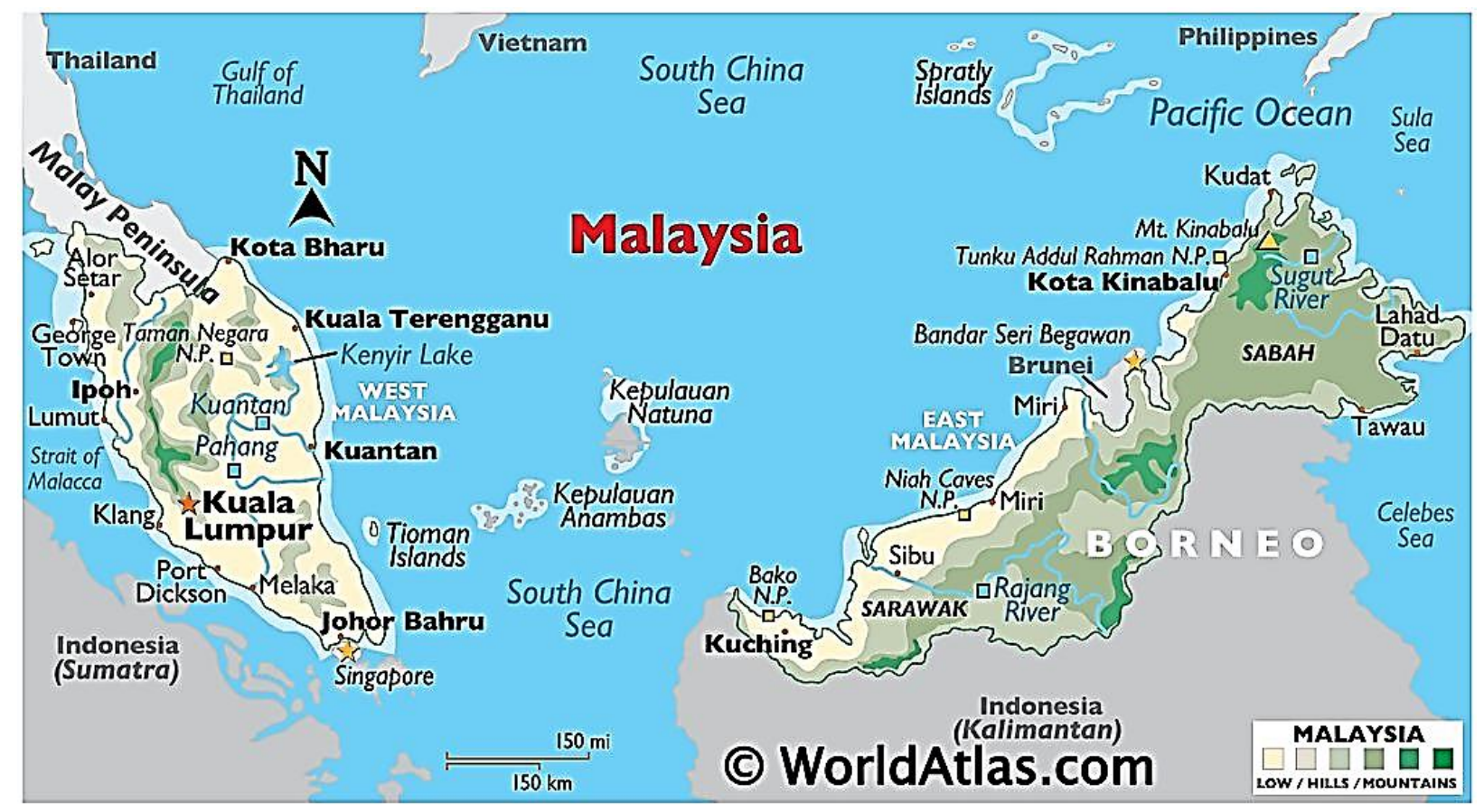

Source: Worldatlas (2021)

Buzan et. al. (1998) said, "Security is about survival." Although the military-political security agenda declined at the end of the Cold War, the broader security agenda became dynamic. Economic, environmental, military, political, and social issues are all on the security agenda. Since the September 11 attacks, the world community has been more mindful of maritime security challenges, particularly Malaysia. Piracy and armed 
robbery at sea, trafficking in guns and Weapon of Mass Destructions (WMDs), the threat of slavery, trafficking in persons and drugs, Illegal, Unreported and Unregulated (IUU) fishing, accident at sea, and environmental damage are all examples of severe challenges to maritime security. Various security risks confront Malaysia's maritime security initiatives, the most serious of which are piracy and armed robbery at sea. Other dangers include maritime terrorism, security incursion on Sabah's eastern coast, including kidnap for ransom (KFR) and hijackings by terrorist groups, unresolved maritime boundaries, maritime environmental pollution, and IUU fishing (Mon, 2018).

The existing security situation has become ever more complex, with threats from state and non-state actors posing a danger to the Malaysian waterways, especially from nontraditional security. From 2010 to 2021, the presence of the treats was visible in the maritime security environment over Malaysia. Global security conversation is firmly established to cope with non-traditional security threats (Cook, 2017). This maritime security issue invites emerging power user states such as China, India, Japan, and South Korea, who have economic interests, to address the issue of piracy up to the extent they want to control the Strait of Malacca (Song, 2018; Siti \& Azizuddin, 2011). The worrying fact is that these attacks by terrorists and traditional maritime pirates, especially over the Straits of Malacca, has directly influenced maritime crime in Malaysia (Nurulizwan \& Wan, 2012).

Malaysia is also involved in a complex conflict over the Spratly Islands. There is also a disagreement regarding the Philippines' claim to the state of Sabah. Some challenges limit the Malaysian government and other littoral states addressing maritime crimes. The issues of porous maritime boundary, maritime disputes area, modern organized criminal groups, stateless people, political and economic instability in the southern Philippines, and geographical factors have made it difficult for the state to address the rise of security issues, especially trans-border crimes in Sulu-Celebes Sea. In addition, the incapability, obsolete platforms, and a small military budget to modernize the maritime fleet agencies and Royal Malaysian Navy (RMN) affected the operation, including intelligence-gathering efforts, constant maritime surveillance operation, and enforcement activities (Stach, 2018). Therefore, Malaysia needs to formulate a more comprehensive strategic plan to ensure the sovereignty and security of its waters are guaranteed from any threats that could threaten the stability of peace.

\section{Research Methods}

This study is a qualitative research method. This study used a combination of library and online research. The information data was acquired at the libraries of the General Tun Ibrahim Library of National Defence University of Malaysia's, the Malaysian Armed Forces Staff College (MAFSC) Library, the Malaysian Institute of Defence and Security (MIDAS), and the Ministry of Defence (MINDEF) Malaysia. Meanwhile, numerous online databases and academic resources allow access to previously published academic work in any area for non-printed materials. The following databases were used: ProQuest, JSTOR, Web of Science, Emerald Insight, Science Direct, Google Scholar, The Diplomat, Academia.com, Re-CAAP ISC, ICC-IMB, Research Gates, rsis-ntasia.org, and others. In addition, the search included several other renowned databases. It used the keywords "Non-Traditional Security, maritime security, maritime security cooperation, maritime crime in Malaysia, US-Malaysia, US-Malaysia cooperation, maritime security initiatives, Strait of Malacca, Malaysia defence and security, national security, Celebes Sea, South China Sea, and Regional Maritime Security Initiatives." 


\subsection{Conceptual Framework}

The National Security concepts have been used to investigate the possibility of a partnership between the United States and the Malaysian government in maritime security in Malaysia's strategy for addressing maritime crime issues and challenges. The ability of a state to provide protection and defense of its citizens has been defined as national security (Osisanya, 2021). National security is defined as "a measurable state of a nation's capability to overcome multi-dimensional dangers to its perceived well-being and survival as a nation-state policy through governance...and is extendable to global security by external variables" (Paleri, 2008). According to Ammerdown Group (2016), "national and international security" can be defined as "shared freedom from fear and want, as well as the freedom to live in dignity." It entails social and ecological health rather than risk aversion... and is a universal right." A threat is defined as something that may constrain the government's policy options. To ensure national security, governments must deploy various tools, including political, economic, and military strength and diplomacy (Sussex et al., 2017).

In addition, the government may strengthen regional and global security by "addressing transnational security challenges such as climate change, economic injustice, political exclusion, and nuclear proliferation" (Romm, 1993) and understanding the significant schools of thought on international security that have emerged following the end of World War Two (Bueger, 2015) also, a tool in explaining the national security context in which Malaysian national security adopted. National security actions are now tackling a significantly broader range of phenomena than before (Sussex et al., 2017). The national security of the country's citizens, economy, and institutions is the government's responsibility. Most scholars agree that national security was defined as a defense against military attacks. Currently, it is broadly accepted to include non-military components, often known as Non-Traditional Security (NTS) that includes economic security, crime prevention, energy security, food security, environmental security, cyber security, and other security elements.

Figure 2 shows the research framework, consisting of Independent, Intervening, and Dependent Variables. The Independent Variable in this research is the US-Malaysia Maritime Security Cooperation, the observed entity. The independent variables manipulate, measure, and relate their factors to a significant effect. Meanwhile, The Dependent Variable refers to Malaysia's National Security. Finally, the Intervening Variable is divided into two categories: traditional and non-traditional security, focusing on challenges affecting Malaysia's national security. The concept of national security is used to explain the phenomenon being studied.

Figure 2: Research Framework

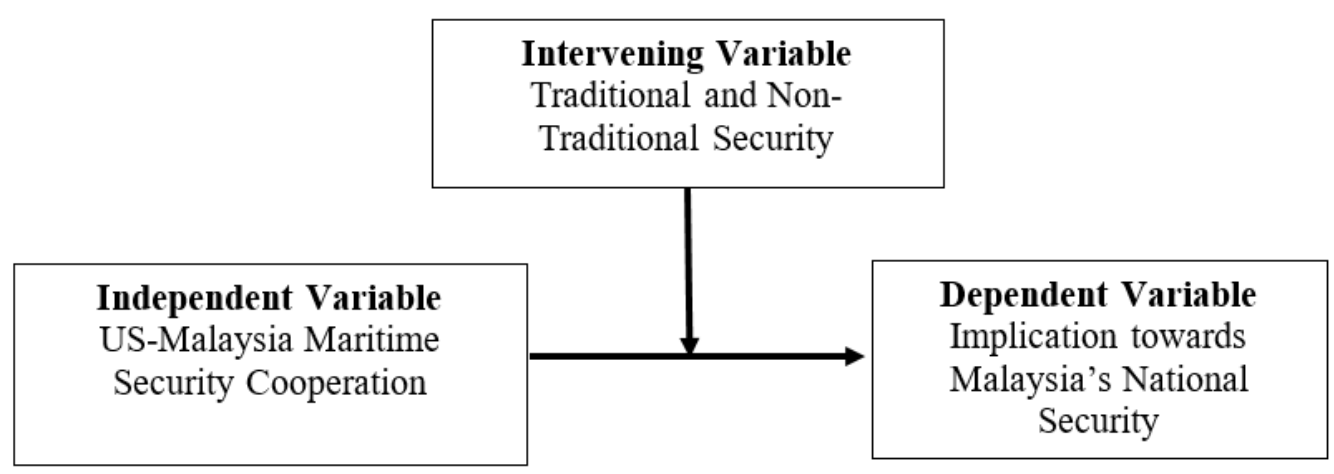




\section{Literature Review}

A literature review is a comprehensive overview of prior research on a particular subject (Hart, 2001; Kaminstein, 2017). It gives an overview of present understanding, enabling the identification of critical ideas, methodologies, and research needs. Searching relevant publications (like books and journal articles), critically evaluating them, and presenting the findings are all part of writing a literature review (Shona, 2021). The literature reviews for this study was divided into two major themes. The first theme is the Malaysian maritime security environment. The second theme focused on maritime security collaboration. The literature reviews on maritime security environment focus on security environment, issues, and challenges in Malaysian waterways, while maritime security cooperation focuses on the scope and benefits of security cooperation. Meanwhile, the research questions are used to guide the ideas.

\subsection{Maritime Security Environment}

The paper titled "The Straits of Malacca: Regional Powers Vis-à-vis Littoral States in Strategic and Security Issues and Interests" by Siti and Azizuddin (2011) outlines the strategic and security issues affecting the Malacca Strait. The study also explored the Strait's strategic nature, the threat of piracy, and the challenges and interests of the Straits' developing countries, such as India, Japan, and China. Due to unresolved piracy issues, the US promised to control the Straits. The article also discusses the positions of the three littoral governments of Indonesia, Malaysia, and Singapore toward collaboration to combat piracy challenges and the differing perspectives of individual states on external power engagement in the Malacca Strait. The primary user states' concern for the security of the Malacca Strait reflects their efforts to protect their respective strategic interests. The importance of the Strait of Malacca for Japan's economic and strategic interest and desire to cooperate in maritime security (financial aids, promotion, training and technical support) is further explained by Noraini (2018) in her article "Straits of Malacca Maritime Strategic Interest towards Japan."

According to Nurulizwan and Wan (2012) in "Maritime violence: implications to Malaysia", maritime piracy has been a significant problem for the world community, particularly in Southeast Asia. Because 45 per cent of the world's shipping flows through Southeast Asia, this threat has had enormous complications for the global economy, the environment, and the political stability of the countries concerned. Terrorist and traditional marine pirate attacks directly impact Malaysian maritime crime. This study indicates that states in the region must cooperate and improve their security systems to curb maritime violence.

Kaska and Pedrozo (2013), in a book titled "International Maritime Security Law", defines an emergent multidisciplinary field of law and policy established of norms, legal frameworks, and regulations to handle today's hybrid challenges to the global order of the oceans. Offshore terrorism, weapons of mass destruction, piracy, smuggling, robbery, marine insurgency, and anti-access threats represent global shipping commerce, fishing fleets, pleasure ships, and coastal states. The international maritime community is now working in an integrated network that combines humanitarian law, human rights law, criminal law, and sea law with a worldwide maritime partnership to defend the maritime domain from the most severe dangers and hazards. 
Bueger (2015) defines maritime security in his article "What Is Maritime Security?" provides frameworks for maritime security, each with its relationship to other concepts and set out in a matrix (marine safety, sea power, blue economy, and resilience), as well as the securitization and security practice theory. The flow of people, goods, money, and information has shifted due to the growing global, transnational crime. A book chapter, "Is Maritime Security a Traditional Security Challenge?" written by Chapsos (2016), debates modern maritime security and surveys the extent of non-traditional security in global maritime security, and there is no fixed definition. The concept of modern maritime security is still debatable, and it is dependent on the perspective of the key stakeholder. Modern maritime security is heavily linked and interdependent with human security and development, distinguishing it from past security issues. New security dangers have evolved in tandem with the development of internet technology, complicated issues even more.

An article titled "Old threats, new approach and national security in Malaysia: issues and challenges in dealing with cross-border crime in the east coast of Sabah" by Ramli et al. (2016) states that formerly permitted cross border activities became illegal after Malaysian was formed in 1963 and pose a security threat to Malaysia. Geographical constraints, such as a porous maritime boundary and maritime conflicts, have made it difficult for the state to manage rising security challenges such as trans-border crimes (armed robberies, incursion and kidnapping for ransom). The "Tanduo incident" in 2013 prompted the preventive security measure such as forming the Eastern Sabah Security Command (ESSCOM). The writer suggested the government should also explore for "non-military approach" to maritime security issues. By utilizing and empowering the function of the Village Security and Development Committees (JKKK), border communities can be engaged and taught about their roles in establishing national sovereignty, restoring peace, law and order, and economic development.

Elina (2017), in her paper "Security Challenges for Malaysia: Defending the Nation-State", states that there are three main security challenges for Malaysia that shape the government policy-making and defense spending for years to come. These challenges are territorial incursions, violent extremism and national integration. According to the writer, the Royal Sulu Force's threat of territorial incursions into the eastern Malaysian state of Sabah has the most significant and direct impact on Malaysia's military policy and defense business. In addition, a series of arrests by the Royal Malaysian Police reveal that the threat of radicalization, violent extremism, and terrorism still exists in Malaysia. Sadly, the government does not prioritize defense and security budgets. Elina (2017) claims that best practices are coordinated patrols in the region's maritime specified regions, collaborative training and drills, and regional counter-narratives.

An article by Azmel and Ikmal (2017) titled "Malaysia's emergency response in the Straits of Malacca" states that in terms of maritime security, it is not just pirate activities, armed robbery and terrorism, that have to be considered. Nevertheless, the other security aspects (maritime safety, personal safety, and environmental disaster) should be given the same importance. Threats to the "safety and security of ships in the Straits of Malacca" could affect Malaysia's reputation and the confidence of the world community in Malaysia's efforts to govern the Strait as the number of ships passing through is steadily increasing. Growing shipping volume increases the dangers to the waterways and coastal states. Collisions and explosions in the straits could obstruct transportation, degrade the environment, and result in revenue losses and economic harm. 
According to Stach (2018) article in "Malaysia's maritime security challenges and the development of the Royal Malaysian Navy: Old problems and new threats," the situation in Southeast Asia calls attention to the region's countries and major powers, particularly those in the South China Sea. In particular, China's increasing economy and military raise concerns about the region's stability as a whole. Malaysia is one of these countries focusing on protecting its national interests. Malaysia's involvement in the Spratly Islands dispute puts the country's maritime security at risk. Insufficient military funding to upgrade the RMN fleet, and outdated platforms, hampered the mission and put the security at a critical stage. Over time, Malaysia gradually improves its naval might by introducing new vessels, such as stealthy submarines and cruisers, as part of the 15 to 5 program.

Daniel (2018a), in his article “Issues impacting Malaysia's maritime security policies and postures", addresses the vital critical points that need to consider in formulating Malaysia's maritime security postures and policies. Five primary challenges are "the consolidation of the wider maritime security framework, the geographic challenge, a lack of resources, the South China Sea dispute, and the security of the Eastern Sabah's Sulu Sea region." "Does Malaysia have a tangible maritime security strategy?" and "is maritime security a national defense or law enforcement matter?" are the queries that arise to explore the issue of maritime security in Malaysia. In addition, external players such as the US Coast Guard and the Japanese Coast Guard appear to be having a significant effect on Malaysia's maritime security competence and understanding. Daniel (2018b) further elaborates about Malaysian traditional and non-traditional security challenges, both internal and external, in his article "Key Issues Impacting Malaysia Security Outlook" and come out with the suggestion that ASEAN Member States (AMS) need to work together even though facing various ongoing border disputes for prospects of regional security or defense cooperation.

Maritime Security and Law Enforcement: The Malaysian Experience, a study by Mon (2018), mentioned that the international community's awareness of maritime security issues increased after September 11. The evaluations of marine law enforcement mechanisms revealed that Malaysia requires a structured national maritime security policy, especially power distribution, to minimize overlapping jurisdiction among authorities. Mon (2018) highlights the necessity for Malaysia's long-term legal and regulatory framework. However, the ageing asset, flaws in the law and limited platform make it difficult to enforce the law, mainly to hunt for non-traditional security issues.

In an article titled "Maritime Security-Malaysia and the South China Sea", written by Aini (2020), the term 'threats' is frequently used in discussions on maritime security. Nontraditional security concerns include crime and terrorism. Regional maritime security coordination is hindered by the interpretation of the Law of the Sea differently by different state actors. Many Chinese vessels have entered Malaysia's EEZ within the South China Sea. This action is a violation of the country's sovereignty and security. In fact, since 2004, the number of Vietnamese fishing vessels has outnumbered those of Chinese vessels in the region. This issue is a significant concern for the food security of the region. If current methods are not changed, the fish stocks in Malaysia's seas will shrink to 59 per cent by 2045 . 


\subsection{Maritime Security Cooperation}

An article titled "Maritime Security and the Straits of Malacca: A Strategic Analysis" by Davis (2006) describes the Malacca Straits "as one of the world's most important" waterways. Terrorism and regional instability have made world-shipping activities unsafe to use this passage. Any significant incident could impede navigation and harm global trade and economic growth. This issue has become a global debate in maritime security agreements and efforts. The U.S. Pacific Command has proposed the Regional Maritime Security Initiatives (RMSI) to provide clear guidance to address the alarming issues. Lessened information sharing and situational awareness, responsive decisionmaking mechanism, asset capability, and collaboration among the actors are the four critical elements necessary for the Strait's security effort.

A report titled "Safety and Security in the Malacca and Singapore Straits. An Agenda for Action" by Bateman et al. (2006) reported that besides piracy and armed attacks, the "Malacca and Singapore Straits are in danger with the terrorist threat after September 11 incident". The concern is more on the safety and security of shipping activities. This report has come out with a 21-point action plan to govern the safety, security, environmental protection and the interest of all stakeholders. The aim is to preserve the safe, accessible and uninterrupted movement in and through the Straits. In addition, there are requirements on the need for cooperation (arrangement or agreement) and information exchange and situational awareness system between the maritime community to ensure the Straits' safety and security.

A discussion paper "Regional Maritime Security Initiatives in the Asia Pacific: Problems and Prospects for Maritime Security Cooperation" by Morada (2006), states that RMSI is still in its early phases in Asia-Pacific, and ASEAN countries have found it difficult to adopt by ASEAN countries by comparing it to existing ASEAN security cooperation mechanisms. This difficulty is due to overlapping interests in dealing with transnational security issues related to maritime concerns, such as sovereignty issues between Indonesia and Malaysia. Therefore, according to Morada (2006), the prospects for longterm maritime security cooperation in the region will be influenced by how players handle their differences on issues of sovereignty, the form of maritime cooperation, burden-sharing issues, and capacity building.

Mak (2008), in his article "Sovereignty in ASEAN and the Problem of Maritime Cooperation in the South China Sea", argues that the "ASEAN is notable for the long peace in the region since the 1908s" only applied to interactions and developments on land, not in maritime issues. However, the 'ASEAN way' promotes conflict resolution without resorting to force or the fear of force. This article explains why maritime cooperation has proved challenging to implement due to territorial disputes, particularly in the South China Sea and the Celebes Sea. Because the 'ASEAN approach' does not yet apply to maritime affairs, it will be challenging to achieve maritime cooperation by comparing the "successful joint development and cooperation in the Gulf of Thailand," collaborative development and cooperation have been successful.

Caceres (2008) wrote in his article "Indonesia, Malaysia, and the Philippines Security Cooperation in the Celebes Sea" explained that there are still challenges in the current limited trilateral security cooperation in the Sulu-Celebes Sea among Malaysia, Indonesia and the Philippines. The trilateral security cooperation has been successfully established to enhance maritime security cooperation in the Celebes Sea (eastern 
Sabah). However, the author contends that the lack of security cooperation is primarily the result of these countries' historical mistrust of one another, particularly in terms of national interests, restricted force projection, domestic political issues, and interagency capacities. The writer also makes recommendations for the US to formulate a strategy to address these issues.

Massey (2008), in an article titled "Maritime security cooperation in the Strait of Malacca", mentions that the sovereignty issues other political interests become an obstacle to achieving successful maritime security cooperation. However, there is better development of the cooperation. This cooperation is due mainly to a decrease in historical conflicts, an increase in extra-regional demand to collaborate, changes in the strategic environment, and the recognition of common maritime terrorism threats postSeptember 11 and maritime crimes. Consequently, multilateral cooperation becomes stable and accepted. In addition, both countries put an extra effort to enhance their maritime assets and procurement strategies to patrol the area. As a result, since 2004, there has been a significant decrease in attacks on vessels in the Malacca Strait.

According to McQuaid et al. (2009) in "Maritime Security: Strengthening International and Interagency Cooperation," the world faces numerous maritime security challenges. In many undeveloped countries, weak maritime security capacity destabilizes impacts and enormous economic loss. Therefore, the international maritime community should build on existing initiatives to tackle maritime security threats. A multi-sector effort is required because military power alone will not solve the issues. Regional cooperation and capacity building are likely the most effective strategies for long-term and sustainable marine security in essential regions. International donor support for local capacity building, improving existing maritime surveillance system interoperability, and integration into future systems is the most impressive "force multiplier" in meeting marine security concerns.

Hiebert et al. (2012) wrote in his article "Political and security cooperation. Developing a 21st- century partnership. From Strength to Empowerment the Next Generation of U.S.Malaysia Relations" mentions that the US-Malaysia relations are at a highest, with both governments dedicated to a new beginning and moving to create closer political, economic, and human links. Relations between the US and Malaysia changed dramatically after Obama and Najib met in 2010 at the nuclear non-proliferation summit in Washington. The main agenda is a long-term connection on security cooperation and politics, trade and investment, education and culture. In addition, the writer claims that the US and Malaysia have common goals in several bilateral and regional domains, including international trade and investment, security and defence, science and technology, human relations, and regional frameworks.

An article titled "Advancing U.S. - Malaysia Security Cooperation in a Changing Environment" by Sullivan (2014) revealed that President Obama and Prime Minister Najib's joint statement declaring the new "comprehensive relationship" focused on trade and economic problems. The Trans-Pacific Partnership (TPP) framework agreement is the most incredible method to improve the US image in Malaysia and the region regardless of any issues and challenges facing Malaysia. The writer suggested that both countries strengthen Malaysia's security and the bilateral security partnership. Kuik (2019), in his article titled "Mapping Malaysia in the evolving Indo-Pacific", explored the opportunities of Malaysia as holding a geostrategic location and suggested that with its 
"non-alignment" principles, "inclusive cooperation", and "shared security", Malaysia could form alliances with any country for its national security.

The article by Song (2018) titled "Security in the Strait of Malacca and the Regional Maritime Security Initiative: Responses to the US Proposal" discloses that the US proposed the RMSI in 2004 and was quickly met with fast responses from Indonesia, Malaysia, and Singapore to establish regional maritime security cooperation. The main goals of "RMSI is to develop a partnership of willing nations, to work together under international and domestic law, to identify, monitor and intercept transnational maritime threats, in particular piracy, armed robbery and terrorist attacks at sea." Instead, post-September 11 increasing world attention to address the threat of "maritime terrorism, the proliferation of WMDs and the security of the maritime transport sector."

An article titled "Maritime Cooperation in the Straits of Malacca (2016-2020): challenges and recommend for a new framework" by Noraini et al. (2020) believes that littoral states to Strait of Malacca, Malaysia, Indonesia and Singapore should share the burden of responsibility to maintain the security and safety of the Straits with other user states likes China, India, Japan and South Korea, as they used the waterway regularly. According to the study's findings, "traditional and non-traditional security threats" continue to pose security problems in the Strait. Despite budgetary and infrastructure challenges, these littoral states are dedicated to enhancing maritime security and safety measures in the Malacca Strait, safeguarding the safety and security of such important Sea Lines of Communication through maritime security cooperation. Agastia (2021), in an article titled "Maritime security cooperation within the ASEAN institutional framework: A gradual shift towards practical cooperation", concludes that maritime security cooperation among ASEAN nations continues to increase, focusing on dialogue and a few examples of practical cooperation.

Lastly, some articles and news were released that the US government continue to assist the Malaysian government in improving maritime security efforts and maritime domain awareness over the Malaysian waterways. For example, articles titled "Drone Delivery Puts the Focus on US-Malaysia Security Cooperation" by Parameswaran (2020), and "Malaysian Begins Conversion of CN235-220M to Maritime Surveillance Aircraft" by Gain (2020) reports that Malaysia continues to upgrade her maritime assets assisted by the US. In addition, there are multiple reports such as "U.S. Navy, Malaysia's air force hold the South China Sea bilateral exercises" by Adamczyk (2021) and "The US interest in bilateral relations with Malaysia remains strong" by Bernama (2021) reveals that Malaysia and the US bilateral relationship continues to remain strong through defence diplomacy, economy and political cooperation.

\subsection{Analysis}

The security situation in Malaysia's waterways has improved year over year. However, maritime crimes are still occurring during the COVID-19 pandemic. The piracy cases that previously propelled the Malaysian SLOC into the spotlight are now at an all-time low, evidenced by the latest ICC-IMB Report. However, Malaysia faces non-traditional security threats such as illegal fishing, smuggling, and human trafficking. In order to eliminate maritime criminal activities, the littoral governments' maritime authorities must work together more closely to develop a complete security situation that addresses the core causes of criminal activity. The value of Malaysian waterways to the global maritime community is demonstrated by international attention to security 
challenges in the SOM and the SCS. Due to limitations and incapability of assets and resources, Malaysia cannot safeguard and maintain its national security stability on its own to address these maritime crimes. Furthermore, Malaysian waterways are the world's busiest sea route. Therefore, Malaysia should benefit from bilateral cooperation with one of the world's major powers, such as the US, to gain maritime security stability, reduce capability gaps, mutual support and interest, assistance, capacity building, law enforcement cooperation, and collaborative partner enhance maritime capabilities. Besides that, as a non-aligned country, Malaysia can enter into bilateral cooperation arrangements or agreements with any country to stand as a neutral country.

Regional and international organizations, non-governmental and commercial organizations, have responded to these threats. Besides providing a good navigation safety service, various initiatives have been identified and positively proven to address maritime issues. Malaysia faces one of the significant threats in modern Maritime Theft, Robbery, and Piracy at Sea (Maritime TRAPS) in the area of concern. However, maritime boundary delimitation in the SOM, the SCS, and the Sulu Sea remains unsolved. The condition has resulted in a hazy territorial division in the Strait, hindering law enforcement, which is the primary goal in ensuring the Strait's safety. The Sulu Sea has always been a hotspot for kidnapping and ship hijacking, even though the incidents not extensively studied and underreported in the mass media may be due to the sensitivity of national sovereignty. Unresolved maritime limits in the Strait also touch on the region's most contentious issue: sovereignty. The littoral governments of the SOM and the Sulu Sea regard the issue of sovereignty to be the most crucial factor in all decisions concerning the Strait. The most important thing, though, is to broaden the scope of the cooperative framework.

Malaysia's strategic position has become the international community's focus on its ability to protect international waters, especially the SOM and the SCS. Maritime security always described the threats in the maritime domain, either traditional or nontraditional security. For example, the safety of the ship's navigation that travels over the sea is often discussed as a part of maritime security. Presently, non-traditional security issues are a significant source of concern for Malaysia that can influence regional environment stability, especially its national security and significant international user strategic interest. The modern Maritime TRAPS and organized crimes become further vulnerable, especially in the SOM. The Sulu Sea (eastern Sabah) is always highlighted with kidnap for ransom and militant activities. Disputes claims in the SCS and illegal fishing activities by Vietnamese fishing boats are the other maritime issues faced by the Malaysian government. Some challenges identified, namely political and public influence, geographical constraint, limitation of capabilities, lack of response from legal and enforcement agencies, agencies working in silos, organized crimes with the latest technology, less coordinated surveillance effort or power distribution, gives indication and warning that required holistic government approach to tackle the emerging issues. "Push-pull" factors for the illegal immigrants also demanded the most suitable future action plan. Therefore, Malaysia seeks bilateral security cooperation and assistance from foreign countries like the US to tackle these issues, effectively enabling mitigation.

Maritime security cooperation is a strategic strategy that incorporates the US and Malaysian governments and numerous maritime security agencies and organizations like the MMEA, MAF, and Royal Malaysian Customs. This collaboration aims to improve the coordination and interoperability of the various actors in the maritime security domain. Other than that is to strengthen regional and global stability more effectively 
and efficiently. The activities involve assistance in aids, education, training and operation to execute the security cooperation missions. No country or agency can offer complete security in the maritime domain without confronting common threats. Furthermore, Both the US and Malaysia are committed to strengthening their partnership through trade, investment, and security. The various factors identified to shape the formation of maritime security cooperation between Malaysia and the US. Sometimes, cooperation occurs when policies are developed for mutual benefit and common interest. The relationship between the US and Malaysia was established upon the independence of Malaysia from Britain in 1957. After Cold War and September 11 incident, the US and Malaysia relationship has reached its most profound level. The reason is due to the shifting of the US Foreign Policy after the incident. Political and economic ties mainly reinforce the relationship and cooperation. Since the 1990s, the US could help Malaysia bolster information sharing, intelligence exchange, and capacitybuilding programs to hunt down common maritime threats with solid security and defense relationship. Bilateral military exercises and visits took place frequently between both countries that serve as part of its defense diplomacy and enhance interoperability of its assets. The US assistance to Malaysia focuses on human capital development, including education, security, and counter-terrorism. Malaysia can improve the RMAF's aircraft and offer UAVs for RMN under the initiative of MSI. The assets are likely to be used for maritime surveillance and ISR operations by the RMAF and the RMN.

Malaysia obtains various benefits, including avoiding conflicts with neighboring countries, economic and political stability, sharing common interests in fighting terrorism, pursuing higher education in developed countries such as the US, and formulating an inclusive and neutral foreign policy. A wide range of diplomatic, strategic, economic, and security-related agreements and arrangements anchor Malaysia's foreign policy posture in the region and strengthen the security guarantee. The other positive payback is Malaysia gained and strengthened greater regional cooperation acceptance, developing confidence building, international recognition, self-capacity building, booster economic and health security, sustainability trade investment, latest technology sharing, intelligence and information exchange, and legal advice. Malaysia benefited from security cooperation with the US, resulting in an agreement between the two nations to strengthen their cooperative partnership "via multi-level engagements" in the postCOVID-19 pandemic. Malaysia and the US are expected to strengthen bilateral cooperation in trade and investment, defense and security and people-to-people connectivity. They are also inclined to work together in areas where their interests overlap or have complimentary benefits. Public health, border security, digital connection, supply chain restructuring, sustainable development, green technology, and capacity-building are just a few examples. Vaccines, in particular, represent a promising area of bilateral public health cooperation based on shared interests between the two parties.

\section{Conclusion}

The US ' foreign policy has evolved dramatically from the end of the Cold War through the September 11 terrorist attacks. These significant events have also resulted in an international and domestic shift in policy decision-making and ties with other countries, particularly in the Indo-Pacific region. Indirectly, it influenced Malaysia in various ways, including politically and economically relations with the US. Because of their shared interests, both countries' military and security cooperation has improved. This shared 
interest helped to understand better the importance of bilateral and multilateral agreements between the US and Malaysia and other countries in the area. Acknowledging the US' worldwide hegemony and the vast economic market is one of the most promising ways for the two countries to define and stabilize their relations. At the same time, the United States appears to be attempting to gain an advantage on Malaysia's strategic location in Southeast Asia. Malaysia might also influence and improve both countries' network connectivity to establish mutual military assistance and enable new and developing markets in technology-related services, higher education, health security, and renewable energy based on mutual interest and understanding. In addition, both countries continue to increase their cooperation in terms of political, economic, and defense diplomacy as potential strategies for the USMalaysia relationship. Finally, the idiosyncrasies of its leader, as well as the historical background of both countries' relationships, are among the factors that influence policy formulation in areas such as developing foreign policy, national security policy, international political economy, and others, all of which contribute to a better relationship between the US and Malaysia.

\section{Acknowledgement}

Part of this article was extracted from a master thesis submitted to National Defence University of Malaysia, Kuala Lumpur.

\section{Funding}

This study received no funding.

\section{Conflict of Interests}

The authors declare no conflict of interest in this study.

\section{References}

Adamczyk. (2021, April 7). U.S. Navy, Malaysia's air force hold South China Sea bilateral exercises. Defence News. https://www.upi.com/DefenseNews/2021/04/07/malaysia-navy-airforce-exercisessouthchinasea/3031617822606/

Agastia, I. G. B. D. (2021). Maritime security cooperation within the ASEAN institutional framework: A gradual shift towards practical cooperation. Journal of ASEAN Studies, 9(1), 25-48, https://doi.org/10.21512/jas.v9i1.6919

Aini, N. M. D. (2020). Maritime Security-Malaysia and the South China Sea. Malaysia Institute of Defence and Security. http://midas.mod.gov.my/gallery/publication/midas-commentaries/219maritime-security-malaysia-and-south-china-sea-by-nor-aini-binti-mohd-nordin

Ammerdown Group. (2016). Rethinking Security: A Discussion Paper. rethinkingsecurity.org.uk. https://rethinkingsecurityorguk.files.wordpress.com/2016/10/rethinkingsecurity-a-discussion-paper.pdf

Azmel, N. A. \& Ikmal, M. H. A. (2017). Malaysia's emergency response in the straits of Malacca. Maritime Institute of Malaysia. 
Bateman, S. Raymond, C. Z. \& Ho, J. (2006). Safety and security in the Malacca and Singapore Straits. An agenda for action. Institute of Defence and Strategic Studies. https://www.files.ethz.ch/isn/26417/IDSS\%20S\&S\%20book.pdf

Bernama. (2021, July 7). The US interest in bilateral relations with Malaysia remains strong. https://www.astroawani.com/berita-malaysia/kepentingan-dalamhubungan-dua-hala-dengan-malaysia-kekal-kukuh-148575

Bueger, C. \& Edmunds, T. (2017). Beyond seablindness: a new agenda for maritime security studies. International Affairs, 93(6), 1293-1311. https://doi.org/10.1093/ia/iix174

Bueger, C. (2015). What is maritime security? Marine Policy. https://www.researchgate.net/publication/270107474_What_is_maritime_securit $\mathrm{y}$

Buzan, B., Wæver, O. \& De Wilde, J. (1998) Security: A new framework for analysis. Lynne Rienner Publishers, Boulder.

Caceres, A. (2008). Indonesia, Malaysia, and the Philippines Security Cooperation in the Celebes Sea. Naval Postgraduate School, Monterey, CA. https://core.ac.uk/download/pdf/36697803.pdf

Central Intelligent Agency (CIA). (2021). Malaysia. https://www.cia.gov/theworldfactbook/countries/malaysia/

Chapsos, I. (2016) Is maritime security a traditional security challenge? In: Masys A. (eds) Exploring the security landscape: non-traditional security challenges. Advanced Sciences and Technologies for Security Applications (ASTSA). Springer. https://doi.org/10.1007/978-3-319-27914-5_4

Commonwealth Governance. (2021). Geography of Malaysia. https://www.commonwealthgovernance.org/countries/asia/malaysia/

Cook, A. (2017). Non-traditional Security and World Politics. Issues in 21 ${ }^{\text {st }}$ Century World Politics, 38-51. http://dx.doi.org/10.1057/978-1-137-58900-2_4

Daniel, T. (2018a). Issues impacting Malaysia's maritime security policies and postures. Japan Institute of International Affairs. In: Column: (Indo-Pacific Focus), 3. https://www.isis.org.my/2018/06/16/issues-impacting-malaysias-maritimesecurity-policies-and-postures-2/

Daniel, T. (2018b). Key issues impacting Malaysia's security outlook. In Security outlook of the Asia-Pacific countries and its implications for the defense sector. NIDS Joint Research, 16. 29-42. National Institute for Defence Studies. http://www.nids.mod.go.jp/english/publication/joint_research/series16/pdf

Davis, J. (2006). Maritime Security and the Straits of Malacca: A Strategic Analysis [Master's thesis, University of the State of New York]. US Army Command and General Staff College. https://apps.dtic.mil/sti/pdfs/ADA479400.pdf

Elina, N. (2017). Security challenges for Malaysia: defending the nation state. Security Outlook of the Asia Pacific Countries and Its Implications for the Defense Sector, (15) 62-71. NIDS Joint Research. http://www.nids.mod.go.jp/english/publication/joint_research/series15/pdf/cha pter04

Hart, C. (2001). Doing a literature review. Sage Publications Ltd.

Hiebert, M., Elina, N., Poling, G. \& Yean, T. S. (2012). Political and security cooperation. developing a 21st- century partnership. from strength to empowerment the next generation of U.S.-Malaysia relations. Institute of Strategic and International Studies.

https://www.jstor.org/stable/resrep13575?seq=1\#metadata_info_tab_contents

Kaminstein, D. (2017). Writing a literature review for an applied master's degree. https://repository.upenn.edu/cgi/viewcontent.cgi?article 
Kaska, J. \& Pedrozo, R. A. (2013). International Maritime Security Law. Martinus Nijhoff Publishers.

Kuik, C. (2019). Mapping Malaysia in the evolving Indo-Pacific construct. Regional Security Outlook 2020. CanPrint Communications.

Labuan Business One Platform. (2021). Why Malaysia is the international business destination choice in Asia. https://www.labuanbusiness.com/why-malaysia-is-theinternational-business-destination-choice-in-asia/

Mak, J. N. (2008). Sovereignty in ASEAN and the Problem of Maritime Cooperation in the South China Sea. (RSIS Working Paper, No.156-08). Nanyang Technological University. https://hdl.handle.net/10356/88093

Maniati, I. L. (1998). The management of the sea lanes of communication in South East Asia and the ASEAN Regional Forum's Performance. ELIAMEP Working Papers. Hellenic Foundation for European and Foreign Policy (ELIAMEP). ETH Zurich. https://css.ethz.ch/en/services/digital-

library/publications/publication.html/23243

Massey, A. S. (2008). Maritime security cooperation in the Strait of Malacca. Washington Naval

School. https://www.researchgate.net/publication/235156843

McQuaid, Julia \& Voelker (2009). Maritime security: strengthening international and interagency cooperation. CNA Conference Report. Center for Naval Analyses. https://www.cna.org/CNA_files/PDF/D0020861.A1.pdf

Mon, S. W. (2018). Maritime security and law enforcement: the Malaysian experience. Kuala Lumpur: International Islamic University Malaysia. https://lib.iium.edu.my/mom/services/mom/document/getFile/B6ppAQWHLbG RtjLS1dS7ozouKcjMLA7020190103115207706

Morada, N. M. (2006). Regional Maritime Security Initiatives in the Asia Pacific: Problems and Prospects for Maritime Security Cooperation. First Berlin Conference on Asian Security (Berlin Group). https://www.swpberlin.org/publications/products/projekt_papiere/Morada_ks.pdf

Noraini, Z. (2018). Straits of Malacca maritime strategic interest towards Japan. International Journal of Research in Social Sciences, 8(4), 240-259. https://www.ijmra.us/project\%20doc/2018/IJRSS_APRIL2018/IJMRA-13560.pdf

Noraini, Z., Raja, I. R. I., Azrul, A. A. R. \& Amer, F. M. Y. (2020). Maritime Cooperation in the Straits of Malacca (2016-2020): challenges and recommend for a new framework. Asian Journal of Research in Education and Social Sciences, 2(2), 10-32. https://www.researchgate.net/publication/341915415_Maritime_Cooperation_in_ the_Straits_of_Malacca_2016-

2020_Challenges_and_Recommend_For_a_New_Framework

Nurulizwan, A. Z. \& Wan, S. A. W. (2012). Maritime violence: implications to Malaysia. Arena Hukum, 6(1), 1-74. http://dx.doi.org/10.21776/ub.arenahukum.2012.00501.6

Osisanya, S. (2021). National security versus global security. United Nations. https://www.un.org/en/chronicle/article/national-security-versus-globalsecurity

Paleri, P. (2008). National security: Imperatives and challenges. Tata McGraw-Hill.

Parameswaran, P. (2020). Drone Delivery Puts the Focus on US-Malaysia Security Cooperation. The Diplomat. https://thediplomat.com/2020/03/drone-deliveryputs-the-focus-on-us-malaysia-security-cooperation/

Ramli, D., Shawaluddin, W. W. H., Diana, P. \& Zaini, O. (2016). Old threats, new approach and national security in Malaysia: issues and challenges in dealing with cross- 
border crime in east coast of Sabah. Mediterranean Journal of Social Sciences, 7(3), 178-186. MCSER Publishing. http://dx.doi.org/10.5901/mjss.2016.v7n3s1p178

Romm, J. J. (1993). Defining national security: the non-military aspects. Council on Foreign Relations. https://www.jcie.org/researchpdfs/NewSecurity/2_Introduction.pdf

Shona, M. C. (2021, August 27). How to write a literature review. https://www.scribbr.com/dissertation/literature-review/

Siti, Z. I. \& Azizuddin, M. M. S. (2011). The Straits of Malacca: regional powers vis-à-vis littoral states in strategic and security issues and interests. Political Managements and Policies in Malaysia. Seminar on National Resilience. https://core.ac.uk/download/pdf/12118559.pdf

Song, Y. (2018). Security in the Strait of Malacca and the Regional Maritime Security Initiative: Responses to the US Proposal. International law studies, 83(9), 97-156. https://digitalcommons.usnwc.edu/cgi/viewcontent.cgi?article $=1163 \&$ context=ils

Stach, L. (2018). Malaysia's maritime security challenges and the development of the Royal Malaysian Navy: Old problems and new threats. Korean Journal of Defence Analysis, 30(3), 423-436. https://www.researchgate.net/publication/330215687

Sullivan, A. (2014). Advancing U.S. - Malaysia security cooperation in a changing environment. Asia Strategy Series. Center for a New American Security. https://www.cnas.org/reports/p17

Sussex. M., Clarke, M. \& Medcalf, R. (2017). National security: between theory and practice. Australian Journal of International Affairs, 71, 474-478. https://doi.org/10.1080/10357718.2017.1347139

WorldAtlas (2021). Maps of Malaysia. WorldAtlas.com. https://www.worldatlas.com/maps/malaysia 